\title{
Abundance of invertebrate prey for birds on organic and conventional arable farms in the Netherlands
}

\author{
S. KRAGTEN, W. L. M. TAMIS, E. GERTENAAR, S. M. MIDCAP RAMIRO, \\ R. J. VAN DER POLL, J. WANG and G. R. DE SNOO
}

\begin{abstract}
Summary
As a result of agricultural intensification, populations of farmland birds have been in steep decline for several decades. Reduction in food abundance has been mentioned as one factor behind these declines. Extensive farm management, such as use of organic methods, is expected to provide more food for birds. In this study we compared invertebrate prey abundance for birds during the breeding season between organic and conventional arable farms. We made comparisons for three different groups of birds: ( 1 ) birds feeding on soil-living invertebrates (earthworms), (2) birds feeding on ground-dwelling invertebrates and (3) birds feeding on aerial invertebrates. Invertebrate abundance was compared between organic and conventional farms, crop and non-crop habitats, and between crop and non-crop habitats under the same farm management. On organic sites, earthworm abundance was 2-4 times higher than on conventional sites, but no differences were found between crop types. Total abundance of ground-dwelling invertebrates did not differ between organic and conventional sites, but positive effects were found for several individual taxonomic groups, such as carabid beetles and spiders. On organic farms, invertebrate abundance was higher in carrots, cereals and onions compared to other crops; on conventional farms this was true for onions. When compared with most crops, ground-dwelling invertebrate abundance was low in uncropped field margins and on ditch banks. On organic farms, aerial invertebrate abundance was approximately $70 \%$ higher than on conventional farms. On cereal fields, aerial invertebrates were especially abundant.
\end{abstract}

\section{Introduction}

The past few decades have seen a dramatic intensification of arable farming, characterised by increased pesticide usage, high inputs of artificial fertilisers, removal of non-crop habitats (such as hedgerows and ditches), larger fields and reduced crop diversity (Medley et al. 1995, Chamberlain et al. 2000, Stoate et al. 2001, Robinson and Sutherland 2002). At the same time, populations of bird species associated with arable landscapes have shown a marked decline (e.g. Krebs et al. 1999, Donald et al. 2001, 2006, Wretenberg et al. 2006).

One of the mechanisms believed to contribute to the decline of farmland bird populations is a reduction in the availability of invertebrate prey, one of the most important food sources for adults, and especially chicks, of most farmland bird species (Wilson et al. 1999, Benton et al. 2002, Holland et al. 2006). In agricultural areas, invertebrate populations have declined as a result of several changes in farming practice (cf. Robinson and Sutherland 2002): (1) increased pesticide use, (2) a switch from organic manure to artificial fertilisers, and (3) loss of semi-natural habitats.

An array of studies has shown that breeding bird densities are higher on organically managed farms (e.g. Christensen et al. 1996, Chamberlain et al. 1999, Beecher et al. 2002, Kragten and de 
Snoo 2008). One of the factors suggested as being responsible is the greater availability of food on organic farms (e.g. Christensen et al. 1996). Several studies have focused on differences in invertebrate abundance between organic and conventionally managed farms (e.g. Hole et al. 2005). However, most studies focused on only one taxonomic group of invertebrates and in most cases only one crop type was investigated. Farmland birds have different diets and diets often have a diverse prey composition (Holland et al. 2006). In order to assess the food abundance for farmland birds on farms it is therefore necessary to focus on a wide range of taxonomic groups of invertebrates. Besides this, crop type is likely to influence food availability as a result of crop management and sward structure (e.g. Atkinson et al. 2005, Hole et al. 2005). However, so far it is unknown which crop types provide most food for farmland birds under organic or conventional management.

The present paper seeks to analyse whether organic arable farms provide insectivorous farmland birds with more prey items during the breeding season than conventionally managed farms. To this end, three studies were designed, each focusing on a different group of invertebrates: soildwelling invertebrates (earthworms), ground-dwelling invertebrates (carabids, spiders, etc.) and aerial invertebrates. These groups represent the main prey items of different avian feeding guilds: (1) birds feeding mainly on earthworms (e.g. Lapwing Vanellus vanellus), (2) birds feeding mainly on invertebrates active on the ground surface (e.g. Skylark Alauda arvensis) and (3) birds feeding mainly on aerial invertebrates (e.g. Barn Swallow Hirundo rustica). The abundance of each invertebrate group on organic and conventional farms was compared at both farm level and crop level. A comparison was also made of invertebrate abundance on different crop types under the same type of farm management. In this way, not only was an overall picture obtained of the effects of organic farming on bird food abundance, but insights were also obtained into which types of crop potentially provide the greatest availability of food items. Breeding bird surveys have also been carried out on the same farms included in this study (Kragten and de Snoo 2008, Kragten et al. 2009). Consequently, this study could provide additional insight into the effects of differences in food abundance between organic and conventional arable farms on breeding bird densities.

\section{Methods}

\section{Study site and data collection}

The different studies were all carried out on organic and conventional arable farms in the province of Flevoland $\left(52^{\circ} 34^{\prime} \mathrm{N} 5^{\circ} 39^{\prime} \mathrm{E}\right)$, the Netherlands, in spring 2004 and 2005 . Farms were selected in two sub-areas: Oostelijk Flevoland and Noordoostpolder, both consisting of polders reclaimed during the 1950 os and 1930s respectively. The soil type is therefore of marine clay origin. The main form of land use in the study area is agricultural (64\% of total area). Of the farmland, $75 \%$ is used for arable farming, $13 \%$ for grassland and $12 \%$ for other types of agriculture. Approximately $8 \%$ of the farmland is managed organically (Bakker 2007). The landscape is very homogeneous and open. Natural habitats consist mainly of woodland patches, grass margins and artificial watercourses. The main differences between the two sub-areas are: (I) somewhat smaller parcels in Noordoostpolder and (2) trees are generally older in Noordoostpolder. In both sub-areas, 1o conventional and Io organic farms were selected. A pairwise analysis was used for farm selection, with each pair consisting of one organic and one conventional farm. Both farms within a pair were surrounded by similar landscape elements, such as woodlots, tree lines, roads, power lines and wind turbines. The distance between farms was at least $600 \mathrm{~m}$. Because of the homogeneous landscape, between-pair variation of the surrounding landscape was very limited. On-farm habitat factors, such as crop and non-crop habitats were not included in the pairing protocol as they constituted essential differences between the two farming systems and were a direct result of farm management. Consequently, there were large differences in crop composition between the two farm types (Table I). On average, about $3-4 \%$ of the farm area 
Table 1 . Differences in crop type between organic and conventional arable farms, showing mean relative farm area $( \pm S D)$ with each crop and percentage of farmers growing the crop. Crop diversity is expressed as the Shannon-Wiener index.

\begin{tabular}{|c|c|c|c|c|c|c|c|c|c|c|}
\hline \multirow{3}{*}{$\begin{array}{l}\text { Year } \\
\text { Farm type }\end{array}$} & \multicolumn{5}{|c|}{2004} & \multicolumn{5}{|c|}{2005} \\
\hline & \multicolumn{2}{|c|}{ Organic $(n=10)$} & \multicolumn{3}{|c|}{ Conventional ( $n=10)$} & \multicolumn{2}{|c|}{ Organic $(n=20)$} & \multicolumn{3}{|c|}{ Conventional $(n=20)$} \\
\hline & $\begin{array}{c}\text { Area } \\
(\%)\end{array}$ & $\begin{array}{l}\text { Farms } \\
(\%)\end{array}$ & $\begin{array}{c}\text { Area } \\
(\%)\end{array}$ & $\begin{array}{l}\text { Farms } \\
(\%)\end{array}$ & Sig. & $\begin{array}{c}\text { Area } \\
(\%)\end{array}$ & $\begin{array}{l}\text { Farms } \\
(\%)\end{array}$ & $\begin{array}{c}\text { Area } \\
(\%)\end{array}$ & $\begin{array}{l}\text { Farms } \\
(\%)\end{array}$ & Sig \\
\hline Potatoes & $19 \pm 4$ & 100 & $28 \pm 6$ & 100 & * & $16 \pm 9$ & 85 & $27 \pm 8$ & 95 & $* *$ \\
\hline Spring cereals & $28 \pm 8$ & 100 & $4 \pm 6$ & 30 & $* *$ & $27 \pm 11$ & 100 & $5 \pm 9$ & 30 & $* * *$ \\
\hline Onions & $11 \pm 7$ & 70 & $11 \pm 9$ & 70 & NS & $11 \pm 7$ & 75 & $11 \pm 10$ & 65 & NS \\
\hline Sugar beet & $5 \pm 11$ & 20 & $16 \pm 9$ & 80 & * & $2 \pm 5$ & 15 & $15 \pm 10$ & 80 & $* * *$ \\
\hline Winter cereals & $0 \pm 0$ & $\mathrm{o}$ & $15 \pm 11$ & 70 & * & $\mathrm{o}$ & o & $12 \pm 14$ & 50 & * \\
\hline Carrots & $7 \pm 8$ & 50 & $4 \pm 5$ & 40 & NS & $7 \pm 8$ & 55 & $4 \pm 6$ & 35 & NS \\
\hline Belgian endive & $1 \pm 3$ & 10 & $6 \pm 8$ & 40 & NS & $3 \pm 6$ & 25 & $8 \pm 11$ & 45 & NS \\
\hline Beans & $5 \pm 7$ & 40 & $3 \pm 11$ & 10 & NS & $5 \pm 6$ & 50 & $3 \pm 8$ & 15 & NS \\
\hline Peas & $3 \pm 8$ & 20 & $0 \pm 0$ & o & NS & $6 \pm 8$ & 40 & $1 \pm 4$ & 15 & * \\
\hline Other crops & $21 \pm 17$ & 90 & $12 \pm 16$ & 60 & * & $23 \pm 15$ & 85 & $14 \pm 17$ & 45 & NS \\
\hline Crop diversity & $2.5 \pm 0.3$ & & $2.3 \pm 0.3$ & & NS & $2.6 \pm 0.5$ & & $2.2 \pm 0.4$ & & $*$ \\
\hline
\end{tabular}

$n=$ number of farms. ${ }^{* *}=P<0.001,{ }^{* *}=P<0.005,{ }^{*}=P<0.05, \mathrm{NS}=P>0.05$.

consisted of non-crop habitats. Grassy, semi-natural elements were far more dominant than ditches, reeds or woody elements. Grassy elements comprised grassy field margins and ditch banks. Woody elements consisted mainly of solitary trees and scrub, though some farms had a small hedgerow. Organic farms had slightly more non-crop habitat than conventional farms (2004: $3.7 \%$ vs. $3.1 \%$; $2005: 4.4 \%$ vs. $3.6 \%$ ), although in both years differences were not significant (2004: Wilcoxon, $Z=1.682$, NS, 2005: Wilcoxon, $Z=1.717, \mathrm{NS}$ ). When differences were analysed per habitat type only in 2005 , more woody habitat elements were found on organic farms (Wilcoxon, $Z=2.666, P<0.01$ ), although the absolute difference was small. All the organic farms selected had been managed according to European Union Regulation 2092/91/ EEC for at least five years. On these farms, farmyard manure was used and weeds were controlled mechanically. All the conventional farmers used artificial fertilisers (in some cases manure as well), herbicides, pesticides and fungicides.

In spring 2005 the study on earthworms was carried out. On 1o organic and 1o conventional arable farms, all in the same sub-area, earthworms were sampled in two sampling rounds: the first from 30 March to I April and the second from 28 April to 3 May. These periods coincide with the breeding season of Lapwings, which feed largely on earthworms (Sheldon 2002). On each farm, a maximum of four fields were sampled by taking four $30 \times 30 \times 30 \mathrm{~cm}$ soil cores on each field. Only fields with potatoes, onions, sugar beet, organic spring cereals or bare ploughed fields were sampled, as these were the dominant crop types. During the first sampling round, 61 fields were sampled ( 33 on organic and 28 on conventional farms) and during the second round, 55 fields (29 on organic and 26 on conventional farms).

The study on ground-dwelling invertebrates took place on 20 organic and 20 conventional farms. These invertebrates were sampled for one week (June 1-8) in 2004. During this period many farmland passerines have chicks (e.g. Wilson et al. 1997, Kragten et al. 2008). Grounddwelling invertebrates were sampled using pitfall traps (diameter $11.6 \mathrm{~cm}$, depth $7 \mathrm{~cm}$ ) filled with ethylene glycol diluted with water (1:1). Pitfalls were placed in the dominant crop types of each farm (maximum of six crop types per farm) and, if these were present, in one grassy field margin and on one ditch bank. In all, 25 different crop types were sampled. In each plot four pitfalls were placed, separated by a distance of $15 \mathrm{~m}$. Within the crops the pitfalls were placed at 15, 30, 45 and $60 \mathrm{~m}$ from the field edge. 
Aerial invertebrates were sampled during the same period and on the same farms as grounddwelling invertebrates were sampled. The sampling period coincided with the peak of the Barn Swallow breeding season (Evans et al. 2007). On each farm, aerial invertebrates were sampled in the dominant crop types (maximum six crop types per farm) and, if present, on one ditch bank and in one field margin using two Sticky Traps (Pherobank $\left.{ }^{\circledR}\right)$. Sticky Traps are plastic plates $(25 \times 10 \mathrm{~cm})$ covered on both sides with non-drying and non-drip 'insect-glue'. These traps were attached to $1-\mathrm{m}$ high bamboo poles, thus protruding above the vegetation, and placed at $30 \mathrm{~m}$ and $60 \mathrm{~m}$ from the field edge, where they were left for a period of seven days. The invertebrates trapped were then counted.

\section{Data analysis}

For all three invertebrate groups (soil-dwelling, ground-dwelling and aerial) a three-part analysis of the results was carried out. First, invertebrate abundance on organic and conventional farms was compared. Second, their abundance on organic and conventional crops was compared (for example, organically versus conventionally managed cereal fields). Similar analyses were performed for non-cropped field margins and ditch banks. Third, invertebrate abundance on different crop types was compared with that found in non-crop habitats under the same type of farm management.

Mean invertebrate abundance was calculated per sampled field after $\log _{10}(x+1)$ transformation and used for statistical analysis. For the farm-level comparisons the mean value per crop per farm was multiplied by the relative area occupied by that crop on the farm concerned. In this way a correction was made for inter-farm differences in crop composition. Comparisons were only made when the number of sampled fields was at least five per farm type (Table 2). As aerial invertebrates were sampled in field margins on only four conventional farms, the data on field margins and ditch banks were pooled. In this way, aerial invertebrate abundance in non-crop habitats could be compared with abundance in crops. To analyse differences in invertebrate abundance between organic and conventional farms or crop types, General Linear Mixed Models (GLMM) with Poisson error and logarithm link function were used with farm management (organic/conventional) set as the fixed effect and farm pair as random effect. The farms on which ground-dwelling and aerial invertebrates were sampled were located in two different regions of the study area and therefore, 'region' was included as a random effect in the analyses for these two groups. Because on some farms earthworms were sampled on more than one bare ploughed field, 'farm' was included as a random effect as well. To assess whether the sampling position in

Table 2. Number of fields sampled per crop type and per invertebrate group.

\begin{tabular}{|c|c|c|c|c|c|c|c|c|}
\hline \multirow[t]{3}{*}{ Crop type } & \multicolumn{4}{|c|}{ Earthworms } & \multirow{2}{*}{\multicolumn{2}{|c|}{ Aerial invertebrates }} & \multirow{2}{*}{\multicolumn{2}{|c|}{$\begin{array}{c}\text { Ground surface } \\
\text { invertebrates }\end{array}$}} \\
\hline & & Period 1 & & Period 2 & & & & \\
\hline & \multicolumn{2}{|c|}{ Organic Conventional } & \multicolumn{2}{|c|}{ Organic Conventional } & \multicolumn{2}{|c|}{ Organic Conventional } & \multicolumn{2}{|c|}{ Organic Conventional } \\
\hline Bare ploughed & 30 & 23 & 3 & 6 & - & - & - & - \\
\hline Potatoes & - & - & 6 & 5 & 15 & 16 & 18 & 19 \\
\hline Onions & 1 & 3 & 8 & 8 & 8 & 12 & 14 & 14 \\
\hline Spring cereals & 4 & - & 10 & - & 19 & 4 & 20 & 3 \\
\hline Sugar beet & - & 3 & 2 & 8 & 4 & 12 & 5 & 17 \\
\hline Carrots & - & - & - & - & 7 & 4 & 7 & 5 \\
\hline Winter cereals & - & - & - & - & - & 9 & - & 11 \\
\hline Other crops & - & - & - & - & 18 & 11 & 21 & 20 \\
\hline Field margins & - & - & - & - & 10 & 4 & 13 & 5 \\
\hline Ditch banks & - & - & - & - & 12 & 16 & 20 & 19 \\
\hline
\end{tabular}

$-=$ no fields available for sampling. Other crops are mainly vegetable crops. 
the field had an influence on invertebrate abundance, differences in invertebrate numbers per position were analysed by means of a Kruskal-Wallis test. No systematic effects were found and therefore sampling position was not included in the analyses. Differences in invertebrate abundance between different crop types under the same farm management were analysed using a Kruskal-Wallis test followed by a Bonferroni-like procedure as described by Neter et al. (1996). Analyses were carried out using Genstat 10.0 (GLMM) and SPSS 12.0 (Kruskal-Wallis).

\section{Results}

\section{Earthworms}

Earthworm abundance was generally 2-4 times higher on organic farms and fields. At the farm level, this difference was significant during the first sampling period only (Table 3). At the crop level, too, earthworm abundance on organic farms was generally higher than on conventional farms. During the first sampling period the difference was significant for bare ploughed fields and during the second period for all cropped fields combined (Table 3). Earthworm abundance did not differ significantly among the various crop types.

\section{Ground-dwelling invertebrates}

No evidence was found for greater total abundance of ground-dwelling invertebrates on organic farms (Table 4). In total, 18 taxonomic groups of invertebrates were distinguished, with Carabidae, Diptera and Collembola predominating. At the farm level, the abundance of 13 groups was greater on organic farms and for Carabidae Araneae, Aphididae, Hymenoptera and Cicadellidae these differences were significant. The abundance of 'other Coleoptera' was greater on conventional farms. For all the other groups analysed no significant effects of farm type were found.

At the crop level there was no evidence that organic management led to a greater total invertebrate abundance. However, certain individual taxonomic groups were found to be more abundant in organic crops: Carabidae (cereals and potatoes), Araneae (cereals), Staphylinidae (potatoes), Formicidae (carrots) and 'other invertebrates' (carrots). In cereals, Staphylinidae and Collembola showed the opposite trend. With respect to non-crop habitats, Isopoda were found in greater numbers in organically-managed field margins. In contrast, Carabidae and 'other Coleoptera' were found to be more abundant on conventionally managed ditch banks compared to organically managed ditch banks.

Within a given farm type, total ground-dwelling invertebrate abundance differed significantly between crop types (organic: Kruskal-Wallis, $\chi_{6}^{2}=16.90, P=0.010$; conventional: KruskalWallis, $\left.\chi_{6}^{2}=14.74, P=0.022\right)$. On organic farms, total invertebrate abundance was greatest in

Table 3. Mean numbers ( \pm SE) of earthworms caught on organic and conventional farms and fields.

\begin{tabular}{llllr}
\hline & & Organic & Conventional & $F$ \\
\hline Period I (March 30-April 1) & Farm level & $4.3 \pm 1.9$ & $1.1 \pm 0.3$ & $5.54^{*}$ \\
& Bare ploughed & $4.5 \pm 1.0$ & $1.0 \pm 0.3$ & $11.67^{* *}$ \\
& All crops & $5.4 \pm 5.0$ & $1.4 \pm 0.4$ & 2.30 \\
Period 2 (April 28-May 3) & Farm level & $4.4 \pm 1.0$ & $2.3 \pm 0.8$ & 2.82 \\
& Bare ploughed & - & $4.6 \pm 3.5$ & - \\
& All crops & $4.5 \pm 0.7$ & $1.6 \pm 0.4$ & $10.98^{* *}$ \\
& Onions & $4.3 \pm 0.9$ & $2.0 \pm 0.8$ & 2.80 \\
& Potatoes & $5.2 \pm 2.4$ & $1.0 \pm 0.7$ & 3.97 \\
\hline
\end{tabular}

Significant results are indicated by ${ }^{*}(P<0.05)$ and ${ }^{* *}(P<0.01) .-=$ no fields available for sampling. No significant differences between crop types were found. 
Table 4. Mean number of ground-dwelling invertebrates on organic and conventional farms and crops. $P$ indicates level of significance for difference in abundance between organic and conventional plots.

\begin{tabular}{|c|c|c|c|c|c|c|c|c|c|c|c|c|c|c|c|c|c|c|c|c|c|c|c|c|c|c|}
\hline & \multicolumn{3}{|c|}{ Farm-level } & \multicolumn{3}{|c|}{ Carrots } & \multicolumn{3}{|c|}{ Cereals } & \multicolumn{3}{|c|}{ Onions } & \multicolumn{3}{|c|}{ Potatoes } & \multicolumn{3}{|c|}{ Sugar beet } & \multicolumn{3}{|c|}{ Field margins } & \multicolumn{3}{|c|}{ Ditch banks } & \multirow[b]{2}{*}{$\mathrm{O}>\mathrm{C}$} & \multirow[b]{2}{*}{$\mathrm{C}>\mathrm{O}$} \\
\hline & $\mathrm{O}$ & $\mathrm{C}$ & $F$ & $\mathrm{O}$ & $\mathrm{C}$ & $F$ & $\mathrm{O}$ & $\mathrm{C}$ & $F$ & $\mathrm{O}$ & $\mathrm{C}$ & $F$ & $\mathrm{O}$ & $\mathrm{C}$ & $F$ & $\mathrm{O}$ & $\mathrm{C}$ & $F$ & $\mathrm{O}$ & $\mathrm{C}$ & $F$ & $\mathrm{O}$ & $\mathrm{C}$ & $F$ & & \\
\hline Total & 140.9 & 116.5 & NS & 150.0 & 85.2 & NS & 158.7 & 100.1 & NS & 133.2 & 187.5 & NS & 122.6 & 104.6 & NS & 100.6 & 113.8 & NS & 110.8 & 82.9 & NS & 71.3 & 83.1 & NS & 4 & 3 \\
\hline $\mathrm{Ca}$ & 61.9 & 34.2 & $*$ & 44.9 & 14.0 & NS & 79.9 & 17.9 & * & $37 \cdot 7$ & 69.5 & NS & $55 \cdot 5$ & 21.7 & $*$ & 36.7 & 46.1 & NS & 20.0 & 21.5 & NS & $4 \cdot 4$ & $9 \cdot 4$ & $*$ & 3 & 4 \\
\hline Di & 23.8 & 29.4 & NS & 19.5 & 26.9 & NS & $7 \cdot 4$ & 6.0 & NS & 33.8 & 37.1 & NS & 33.9 & $45 \cdot 9$ & NS & 22.1 & 22.3 & NS & 13.2 & 8.0 & NS & 6.3 & 6.5 & NS & 2 & 5 \\
\hline Co & 15.9 & 25.1 & NS & 46.0 & 15.5 & NS & $4 \cdot 4$ & 23.1 & $* *$ & 33.2 & 50.2 & NS & 14.2 & 20.6 & NS & $15 \cdot 3$ & 13.4 & NS & 3.2 & 6.5 & NS & 4.1 & 6.5 & NS & 2 & 5 \\
\hline Ot & 7.8 & 10.0 & * & 10.9 & 12.7 & NS & 3.9 & 4.4 & NS & 9.3 & 15.0 & NS & 5.6 & 6.5 & NS & 10.7 & 17.6 & NS & 7.4 & 8.8 & NS & 3.2 & $5 \cdot 3$ & $* *$ & o & 7 \\
\hline St & 9.8 & 6.7 & NS & 6.8 & $4 \cdot 3$ & NS & 10.4 & 22.2 & * & 8.6 & 6.0 & NS & 5.1 & 2.9 & $*$ & 4.0 & 3.4 & NS & 8.6 & 4.6 & NS & 4.2 & 4.9 & NS & 5 & 2 \\
\hline $\mathrm{Ar}$ & 8.1 & 3.9 & $* *$ & 4.0 & 2.6 & NS & 12.8 & $5 \cdot 7$ & * & 3.1 & 3.1 & NS & 2.3 & 1.5 & NS & 2.3 & 4.6 & NS & 21.3 & 13.5 & NS & 12.6 & 10.9 & NS & 6 & $I$ \\
\hline Ap & 6.5 & 1.5 & $* * *$ & 11.3 & 1.9 & NS & 13.2 & $4 \cdot 3$ & NS & 1.8 & 1.7 & NS & 1.4 & 1.0 & NS & 1.7 & 0.9 & NS & 3.2 & 3.1 & NS & 2.0 & 1.2 & NS & 7 & o \\
\hline $\mathrm{Ch}$ & 2.3 & 2.2 & NS & 1.5 & 5.2 & NS & 2.8 & 4.6 & NS & 1.8 & 2.0 & NS & 1.8 & 2.0 & NS & 4.5 & $3 \cdot 3$ & NS & 1.2 & 1.9 & NS & 1.4 & 2.9 & NS & 1 & 6 \\
\hline Hy & 1.7 & 0.9 & $*$ & 2.3 & 1.0 & NS & 1.2 & 1.2 & NS & 1.8 & 0.9 & NS & 1.4 & 0.8 & NS & 0.9 & 0.7 & NS & 4.0 & 2.4 & NS & 3.1 & 2.5 & NS & 7 & o \\
\hline Fo & 1.2 & 0.9 & NS & 1.5 & 0.4 & $*$ & 0.9 & 1.1 & NS & 1.2. & 1.0 & NS & 0.6 & 0.5 & NS & 1.4 & 0.8 & NS & $7 \cdot 7$ & 3.9 & NS & $7 \cdot 5$ & 8.7 & NS & 5 & 2 \\
\hline Ac & 0.6 & 0.8 & NS & 0.5 & 0.1 & NS & 0.4 & 1.7 & NS & 0.3 & 0.2 & NS & 0.4 & 0.8 & NS & 0.5 & 0.3 & NS & 3.4 & 2.2 & NS & 3.4 & 4.7 & NS & 4 & 3 \\
\hline $\mathrm{Ga}$ & 0.3 & 0.3 & NS & 0.0 & 0.0 & NS & 0.0 & 0.1 & NS & 0.0 & 0.0 & NS & 0.0 & 0.0 & NS & 0.0 & 0.0 & NS & 4.6 & 3.6 & NS & $7 \cdot 5$ & 10.1 & NS & 2 & 3 \\
\hline $\mathrm{Ci}$ & 0.3 & 0.1 & $* * *$ & 0.2 & 0.4 & NS & 0.1 & 0.1 & NS & 0.1 & 0.1 & NS & 0.0 & 0.0 & NS & 0.0 & 0.0 & NS & 3.9 & 1.1 & NS & 3.6 & 3.8 & NS & 2 & 5 \\
\hline Is & 0.2 & 0.2 & NS & 0.2 & 0.0 & NS & 0.0 & 0.1 & NS & O.O & 0.1 & NS & O.O & O.O & NS & 0.2 & O.O & NS & 1.2 & 0.2 & $* *$ & 4.8 & 5.9 & NS & 4 & 3 \\
\hline $\mathrm{Lu}$ & 0.2 & 0.2 & NS & 0.0 & 0.1 & NS & 0.2 & 0.1 & NS & 0.2 & 0.5 & NS & 0.1 & 0.1 & NS & 0.1 & 0.2 & NS & 0.4 & 0.5 & NS & 0.7 & 0.7 & NS & 2 & 5 \\
\hline $\mathrm{Ph}$ & 0.1 & 0.1 & NS & 0.2 & 0.0 & NS & 0.1 & 0.4 & NS & O.o & 0.0 & NS & 0.1 & 0.0 & NS & O.० & 0.1 & NS & 0.5 & 0.2 & NS & 0.4 & 0.3 & NS & 5 & 2 \\
\hline In & 0.1 & 0.1 & NS & 0.2 & 0.0 & $*$ & 0.0 & 0.1 & NS & 0.3 & 0.1 & NS & 0.0 & 0.1 & NS & 0.0 & 0.0 & NS & 0.8 & 0.9 & NS & 0.7 & 0.5 & NS & 3 & 4 \\
\hline $\mathrm{He}$ & 0.0 & O.O & NS & 0.0 & 0.0 & NS & O.O & O.O & NS & 0.0 & 0.0 & NS & 0.1 & O.O & NS & O.O & O.0 & NS & 0.2 & 0.1 & NS & 0.2 & 0.2 & NS & 2 & 2 \\
\hline $\mathrm{O}>\mathrm{C}$ & \multicolumn{3}{|c|}{13} & \multicolumn{2}{|c|}{11} & \multicolumn{4}{|c|}{7} & \multicolumn{3}{|c|}{8} & \multicolumn{3}{|c|}{12} & \multicolumn{3}{|c|}{8} & \multicolumn{3}{|c|}{12} & \multicolumn{3}{|c|}{5} & & \\
\hline $\mathrm{C}>\mathrm{O}$ & \multicolumn{2}{|c|}{5} & & \multicolumn{2}{|c|}{5} & \multicolumn{4}{|c|}{10} & \multicolumn{3}{|c|}{10} & \multicolumn{3}{|c|}{6} & \multicolumn{3}{|c|}{8} & & 6 & & 1 & 3 & & & \\
\hline
\end{tabular}

$* * * 0.001,{ }^{* *}<$ o.01, ${ }^{*}<$ o.05, NS not significant. Ca $=$ Carabidae, Di $=$ Diptera, Co $=$ Collembola, Ot $=$ other Coleoptera, St $=$ Staphylinidae, Ar $=$ Arachnida, Ap $=$ Aphididae, $\mathrm{Ch}=$ Chilopoda, $\mathrm{Hy}=$ Hymenoptera, $\mathrm{Fo}=$ Formicidae, $\mathrm{Ac}=$ Acari, $\mathrm{Ga}=$ Gastropoda, $\mathrm{Ci}=\mathrm{Cicadellidae}, \mathrm{Is}=\mathrm{Isopoda}, \mathrm{Lu}=\mathrm{Lumbricina}, \mathrm{Ph}=\mathrm{Phalangida}, \mathrm{In}$ $=$ other invertebrates, $\mathrm{He}=$ Heteroptera. 
Table 5. Mean numbers ( \pm SE) of aerial invertebrates caught on organic and conventional farms and over crops and non-crop habitats.

\begin{tabular}{llcc}
\hline & Organic & Conventional & $F$ \\
\hline Farm level & $169.3 \pm 19.2$ & $100.1 \pm 7.9$ & $15.14^{* * *}$ \\
Non-crop habitat & $149.3 \pm 21.4^{\mathrm{b}}$ & $121.3 \pm 8.9^{\mathrm{ab}}$ & 2.62 \\
Onions & $106.4 \pm 17.7^{\mathrm{c}}$ & $106.1 \pm 12.1^{\mathrm{bc}}$ & $0.3^{\mathrm{b}}$ \\
Potatoes & $153.8 \pm 28.4^{\mathrm{b}}$ & $92.9 \pm 10.1^{\mathrm{cd}}$ & $4^{*} 7^{*}$ \\
Cereals & $228.9 \pm 26.3^{\mathrm{a}}$ & $140.7 \pm 18.0^{\mathrm{a}}$ & $12.27^{* *}$ \\
Carrots & $99.4 \pm 9.4^{\mathrm{c}}$ & - & - \\
Sugar beet & - & $82.5 \pm 15.7^{\mathrm{d}}$ & - \\
\hline
\end{tabular}

Significant results are indicated by ${ }^{*}(P<0.05),{ }^{* *}(P<0.01)$ and ${ }^{* *}(P<$ 0.001 $)$. Letters indicate significant differences between crop types within the same type of farm management. Same letters indicate no difference.

carrots, onions and cereals and least on ditch banks. On conventional farms, total invertebrate abundance in onions exceeded that on any other crop.

\section{Aerial invertebrates}

At the farm level, aerial invertebrate abundance was significantly greater on organic farms (Table 5). At the crop level, all comparisons showed greater aerial invertebrate abundance on organic fields as well, but only in the case of potatoes and cereals the differences were significant. In non-crop habitats, aerial invertebrates were more abundant on organic farms, but this difference was not significant (Table 5). On both organic and conventional farms the numbers of aerial invertebrates caught differed from crop to crop (organic: Kruskal-Wallis, $\chi_{4}^{2}=19.22, P=0.001$; conventional: Kruskal-Wallis, $\chi_{4}^{2}=13.70, P=0.008$ ). On both types of farm, aerial invertebrate abundance was greatest over cereal fields. On organic farms, aerial invertebrates were least abundant over carrots and onions and on conventional farms over potatoes and sugar beet.

\section{Discussion}

This study found positive effects of organic farming on the abundance of earthworms and ground-dwelling and aerial invertebrates. Earthworm abundance was 2-4 times higher on organic farms and fields. For a given type of farm management no differences in earthworm abundance between crop types were found. The total abundance of ground-dwelling invertebrates did not differ significantly between farm types, although Carabidae, Araneae, Aphididae, Hymenoptera and Cicadellidae were all more abundant on organic farms. The opposite was true for the group of 'other Coleoptera'. In carrot, cereal and potato fields certain groups were found to be more abundant on organically managed farms. On organic farms ground-dwelling invertebrates were most abundant in carrots, cereals and onions. On conventional farms this held true for onion fields. Compared with most crops, ground-dwelling invertebrate abundance was low in uncropped field margins and on ditch banks. Aerial invertebrates were more abundant on organic farms. At the crop level, significantly higher abundances were found in organically managed cereal and potato fields. Compared with other crop types, aerial invertebrate abundance was greatest in cereal fields. Some caution should be applied when interpreting the results of this study, as ground-dwelling and aerial invertebrates were sampled during a period of one week only.

The greater abundance of earthworms on organic farms may be due to the use of farmyard manure rather than artificial fertilisers, manure constituting an important food resource for earthworms (Pfiffner and Mäder 1997). The absence of pesticide use may also be beneficial, especially for earthworms close to the soil surface (Pfiffner and Mäder, 1997). Many taxonomic groups of ground-dwelling invertebrates were found in greater abundance on organically 
managed than on conventionally managed sites. Possible causes of these differences are absence of pesticide use, richer understorey vegetation and increased food supply (Hole et al. 2005), but these parameters were not measured during the present study. The effects of organic farming on ground-dwelling invertebrates were somewhat inconsistent among crop types. This may be due to differences in farming practice among the various crops, including differences in tillage and pesticide application (Hole et al. 2005). The greater abundance of aerial invertebrates on organic farms was probably caused by the absence of pesticide use and by higher inputs of organic fertilisers. Pesticides inputs are known to have damaging effects on invertebrate populations (e.g. Aebischer 1990, Anderson and Lydy 2002). Higher inputs of organic material are known to have positive effects on the numbers of decomposers like many Diptera species (Smeding and de Snoo 2003).

Landscape composition is known to affect differences in invertebrate abundance and diversity between organic and conventional farming systems (Purtauf et al. 2005, Schmidt et al. 2005, Holzschuh et al. 2007). In this study, the surrounding landscape composition was part of the farm pairing protocol. Besides this, landscape composition of the entire study area was relatively homogeneous. Therefore, it is unlikely that this has influenced the results. On-farm landscape composition differed largely as a result of different crop rotation systems (Table 1 ), but this is a direct effect of different farm management strategies.

Several studies have shown the importance of grassy or herbaceous field margins as foraging sites for birds (e.g. Marshall and Moonen 2002). In our study, the abundance of ground-dwelling invertebrates in field margins was much lower than in crops. This could be a bias resulting from the sampling method adopted. With pitfalls, insect activity density is measured (e.g. Winder et al. 2005). Invertebrate activity depends on vegetation structure and micro-climatic conditions, and therefore comparing invertebrate abundance between different habitats using pitfalls could be biased. Also, comparisons between crops could suffer to some extent from this bias, so some caution should be applied in interpreting these results.

Although overall abundance of ground-dwelling invertebrates was generally lower in uncropped habitats, certain taxonomic groups were more abundant here than in crops (Table 4). Groups characteristic of stable habitats, in particular, were more abundant in field margins and on ditch banks. In addition, most of these groups are detritivorous, hydrophylous or associated with dense vegetation structures.

\section{Implications for birds}

In 2004 and 2005, breeding bird surveys for field-breeding species were carried out on the same farms where the invertebrate surveys took place. Barn Swallow nests were also counted on all these farms during spring 2005. Skylark and Lapwing were both breeding in higher densities on organic farms (Kragten and de Snoo 2008), but there was no difference in the number of breeding Barn Swallows between the two farming types (Kragten et al. 2009). In contrast to Skylarks, breeding densities of other species feeding mainly on ground-dwelling invertebrates, such as Yellow Wagtail Motacilla flava and Meadow Pipit Anthus pratensis, did not differ between the two farming systems. For Lapwing, indications were found that differences in food abundance could play a role in this. Lapwing densities were higher on organic onion fields compared to conventional onion fields, probably an effect of differences in crop management and consequently food abundance. However, for Skylarks no such indications were found. Differences in Skylark densities were mainly caused by differences in crop rotation schemes between the two farming systems.

The present study shows that Lapwing food (earthworms) is indeed more abundant on organically managed farms. In addition to this, Baines (1990) found correlations between Lapwing densities and food abundance. This reinforces the hypothesis that higher Lapwing densities on organic farms are due to greater earthworm abundance. Besides Lapwing, other species feeding on earthworms (e.g. Blackbird Turdus merula, Song Thrush Turdus philomelos) 
are also likely to benefit from organic farm management. Carabidae, Araneae and Aphididae are all relatively abundant in the diets of farmland birds (Wilson et al. 1999, Holland et al. 2006). These groups were found in greater abundance on organic farms. However, no indications were found that these differences have caused differences in densities of birds feeding on these prey items (Kragten and de Snoo 2008). It is likely, though, that Skylarks and other insectivorous passerines will benefit from the greater food abundance in terms of improved breeding success (e.g. Boatman et al. 2004, Hart et al. 2006). Christensen et al. (1996) found greater numbers of Barn Swallows flying over organically managed fields than conventionally managed fields. In the Netherlands however, no difference was found in the number of breeding Barn Swallows (Lubbe and de Snoo 2007, Kragten et al. 2009). The number of breeding Barn Swallows is probably correlated with the availability of suitable breeding sites. This is likely to be the same on organic and conventional farms, as the types of building on both are more or less equivalent (Lubbe and de Snoo 2007). However, the number of foraging swallows shows a positive relationship with prey abundance (Evans et al. 2007). Greater food abundance may therefore result in improved Barn Swallow breeding success, but is not likely to result in higher breeding densities.

Especially for birds feeding on ground-dwelling invertebrates, greater food abundance does not necessarily mean greater food availability as well, for differences in sward structure can lead to differences in availability even if food is equally abundant. Dense, high swards generally limit accessibility (Atkinson et al. 2005) and many birds prefer to forage in short swards (Devereux et al. 2004). As organic farms grow more spring-sown crops compared with conventional farms (e.g. Hole et al. 2005, Kragten and de Snoo 2008), swards are generally lower and food accessibility therefore probably higher.

The present study shows that food abundance for insectivorous breeding farmland birds is higher on organically managed arable farms. It is likely that this will result in higher adult survival rates, breeding success and better fledgling body condition of breeding birds on organic farms. Therefore, organic farming systems could potentially be beneficial for farmland bird populations. However, data on these topics are scarce and therefore future studies should focus on this.

\section{Acknowledgements}

We are grateful to all farmers who gave us permission to work on their land. Bart Goossen and Chantal Kersten assisted during the field work. Nigel Harle edited the English. The comments of two anonymous referees seriously improved the manuscript.

\section{References}

Aebischer, N. J. (1990) Assessing pesticide effects on non-target invertebrates using long-term monitoring and time-series modelling. Funct. Ecol. 4: 369-373.

Anderson, T. D. and Lydy, M. J. (2002) Increased toxicity to invertebrates associated with a mixture of atrazine and organophosphate insecticides. Env. Toxic. Chem. 21: 1507-1514.

Atkinson, P. W., Fuller, R. J., Vickery, J. A., Conway, G. J., Tallowin, J. R. B., Smith, R. E. N., Haysom, K. A., Ings, T. C., Asteraki, E. J. and Brown, V. K. (2005) Influence of agricultural management, sward structure and food resources on grassland field use by birds in lowland England. J. Appl. Ecol. 42: 932-942.

Baines, D. (1990) The roles of predation, food and agricultural practice in determining the breeding success of the lapwing (Vanellus vanellus) on upland grasslands. J. Anim. Ecol. 59: 915-929.

Bakker, J. (2007) Bio-monitor jaarrapport 2006. Utrecht: Biologica. (In Dutch).

Beecher, N. A., Johnson, R. J., Brandle, J. R., Case, R. M. and Young, L. J. (2002) Agroecology of birds in organic and nonorganic farmland. Conserv. Biol. 16: 1620-1631.

Benton, T. G., Bryant, D. M., Cole, L. and Crick, H. Q. P. (2002) Linking agricultural 
practice to insect and bird populations: a historical study over three decades. J. Appl. Ecol. 39: 673-687.

Boatman, N. D., Brickle, N. W., Hart, J. D., Milsom, T. P., Morris, A. J., Murray, A. W. A, Murray, K. A. and Robertson, P. A. (2004) Evidence for the indirect effects of pesticides on farmland birds. Ibis 146 (suppl. 2): 131-143.

Chamberlain, D. E., Fuller, R. J., Bunce, R. G. H., Duckworth, J. C. and Shrubb, M. (200o) Changes in the abundance of farmland birds in relation to the timing of agricultural intensification in England and Wales. J. Appl. Ecol. 37: 771-788.

Chamberlain, D. E., Wilson, J. D. and Fuller, R. J. (1999) A comparison of bird populations on organic and conventional farm systems in southern Britain. Biol. Conserv. 88: 307-320.

Christensen, K. D, Jacobsen, E. M. and Nøhr, H. (1996) A comparative study of bird faunas in conventionally and organically farmed areas. Dansk Ornit. Foren. Tidsskr. 90: $21-28$.

Devereux, C. L., McKeever, C. U., Benton, T. G. and Whittingham, M. J. (2004) The effect of sward height and drainage on Common Starlings Sturnus vulgaris and Northern Lapwings Vanellus vanellus foraging in grassland habitats. Ibis 146 : 115-122.

Donald, P. F, Green, R. E. and Heath, M. F. (2001) Agricultural intensification and the collapse of Europe's farmland bird populations. Proc. R. Soc. B 268: 25-29.

Donald, P. F., Sanderson, F. J., Burfield, I. J. and van Bommel, F. P.J. (2006) Further evidence of continent-wide impacts of agricultural intensification on European farmland birds, 1990-2000. Agric. Ecosyst. Environ. 116: 189-196.

Evans, K. L., Wilson, J. D. and Bradbury, R. B. (2007) Effects of crop type and aerial invertebrate abundance on foraging barn swallows Hirundo rustica. Agric. Ecosyst. Environ. 122: 267-273.

Hart, J. D., Milsom, T. P., Fisher, G., Wilkins, V., Moreby, S. J., Murray, A. W. A. and Robertson, P. A. (2006) The relationship between yellowhammer breeding performance, arthropod abundance and insecti- cide applications on arable farmland. J. Appl. Ecol. 43: 81-91.

Hole, D. G., Perkins, A. J., Wilson, J. D., Alexander, I. H., Grice, P. V. and Evans, A. D. (2005) Does organic farming benefit biodiversity? Biol. Conserv. 122: 113-130.

Holland, J. M., Hutchison, M. A. S., Smith, B. and Aebischer, N. J. (2006) A review of invertebrates and seed-bearing plants as food for farmland birds in Europe. Ann. Appl. Biol. 148: 49-71.

Holzschuh, A., Steffan-Dewenter, I., Kleijn, D. and Tscharntke, T. (2007) Diversity of flower-visiting bees in cereal fields: effects of farming system, landscape composition, and regional context. J. Appl. Ecol. 44: 41-49.

Kragten, S. and de Snoo, G. R. (2008) Fieldbreeding birds on organic and conventional arable farms in the Netherlands. Agric. Ecosyst. Environ. 126: 270-274.

Kragten, S., Reinstra, E. and Gertenaar, E. (2009) Breeding barn swallows Hirundo rustica on organic and conventional arable farms in the Netherlands. J. Ornithol. 150: 515-518

Kragten, S., Trimbos, K. B. and de Snoo, G. R. (2008) Breeding activity of skylarks (Alauda arvensis) on organic and conventional arable farms in The Netherlands. Agric. Ecosyst. Environ. 126: 163-167.

Krebs, J. R., Wilson, J. D., Bradbury, R. B. and Siriwardena, G. M. (1999) The second silent spring? Nature 400: 611-612.

Lubbe, S. K. and de Snoo, G. R. (2007) Effect of dairy farm management on Swallow Hirundo rustica abundance in The Netherlands. Bird Study 54: 176-181.

Marshall, E. J. P. and Moonen, A. C. (2002) Field margins in northern Europe: their functions and interactions with agriculture. Agric. Ecosyst. Environ. 89: 5-21.

Medley, K. E., Okey, B. W., Barrett, G. W., Lucas, M. F. and Renwick, W. H. (1995) Landscape change with agricultural intensification in a rural watershed, southwestern Ohio, U.S.A. Landsc. Ecol. 10: 161-176.

Neter, J., Kutner, M. H. and Nachtsheim, C. J. (1996) Applied linear statistical models. Chicago: Times Mirror Higher Education Group.

Pfiffner, L. and Mäder, P. (1997) Effects of biodynamic, organic and conventional 
production systems on earthworm populations. Biol. Agric. Hortic. 15: 3-10.

Purtauf, T., Roschewitz, I., Dauber, J., Thies, C., Tscharntke, T. and Wolters, V. (2005) Landscape context of organic and conventional farms: Influences on carabid beetle diversity. Agric. Ecosyst. Environ. 108: 165-174.

Robinson, R. A. and Sutherland, W. J. (2002) Post-war changes in arable farming and biodiversity in Great Britain. J. Appl. Ecol. 39: $157-176$.

Schmidt, M. H., Roschewitz, I., Carsten, T. and Tscharntke, T. (2005) Differential effects of landscape and management on diversity and density of ground-dwelling farmland spiders. J. Appl. Ecol. 42: 281287.

Sheldon, R. D. (2002) Factors affecting the distribution, abundance and chick survival of the Lapwing (Vanellus vanellus). Newport: Harper Adams University College.

Smeding, F. W. and de Snoo, G. R. (2003) A concept of food-web structure in organic arable farming systems. Landsc. Urb. Plan. 65: $219-236$.

Stoate, C., Boatman, N. D., Borralho, R. J., Rio Carvalho, C., de Snoo, G. R. and Eden,
P. (2001) Ecological impacts of arable intensification. J. Environ. Manage. 63: 337365.

Wilson, J. D., Evans, J., Browne, S. J. and King, J. R. (1997) Territory distribution and breeding success of skylarks Alauda arvensis on organic and intensive farmland in southern England. J. Appl. Ecol. 34: 1462-1478.

Wilson, J. D., Morris, A. J., Arroyo, B. E., Clark, S. C. and Bradbury, R. B. (1999). A review of the abundance and diversity of invertebrate and plant food of granivorous birds in northern Europe in relation to agricultural change. Agric. Ecosyst. Environ. 75: 13-30.

Winder, L., Alexander, C. J., Holland, J. M., Symondson, W. O. C., Perry, J. N. and Woolley, C. (2005) Predatory activity and spatial pattern: the response of generalist carabids to their aphid prey. J. Appl. Ecol. 74: 443-454.

Wretenberg, J., Lindström, Å., Svensson, S., Thierfelder, T. and Pärt, T. (2006) Population trends of farmland birds in Sweden and England: similar trends but different patterns of agricultural intensification. J. Appl. Ecol. 43: 1110-1120.

\section{S. KRAGTEN*, W. L. M. TAMIS, E. GERTENAAR, S. M. MIDCAP RAMIRO, R. J. VAN DER POLL, J. WANG and G. R. DE SNOO \\ Leiden University, Institute of Environmental Sciences, P.O. Box 9518, 2300 RA Leiden, The Netherlands \\ Current address: Vogelbescherming Nederland, P.O. Box 925, 3700 AX Zeist, The Netherlands}

*Author for correspondence; e-mail: steven.kragten@vogelbescherming.nl

Received 16 March 2009; revision accepted 6 July 2009;

Published online 27 January 2010 